\title{
Adult Education and Lifelong Learning in Post-Communist Countries
}

More than twenty years have passed since the fall of the Berlin wall - which meant a radical change in perspectives for the development of the socialist countries of Central and East Europe, formerly - from a Western perspective - 'behind the Iron Curtain'. These two decades have also seen radical new developments in China - which is fast 'catching up' economically - as well as in the fields of the education of adults and lifelong learning.

As mentioned above, several European post-Communist countries have joined the European Union (EU). In so doing they accepted fiscal and juridical alignment and the Lisbon agenda: they also embraced the idea of lifelong learning. However, alhough adult education had long formed an integral part of these countries' lifestyles, the idea of lifelong learning itself did not necessarily spring from their own historical, cultural or economic backgrounds. In China, lifelong learning has in modern times been closely associated with formalising learning and with state manpower planning.

Post-communist countries are far from a uniform group. They differ from each other in their historical and economic development and in their culture. What made them alike was their mono-party political system. If the word 'communism' or even 'socialism' meant there was 'no private initiative', it also meant free-of-charge education, organised public health care, childcare, social security, social care and job security. As Holford et al. (2008, p. 12) point out 'adult education formed a significant feature of the apparatus of many communist-led states in Central and Eastern Europe'. The same might be said of China since the Revolution of 1949 (Cheng, Jin \& Gu 1998).

With the collapse of the Socialist bloc and changes in China these countries have been facing various challenges - transition from central planned economies to market economies, from collectivism to individualism, from mono-party to multi-party systems. At the same time, as Ma (1998, p. 349) puts it, there was 'mass privatisation in the Czech and Slovak Republics, local government reform in Poland' and the introduction of 'state-market-civil institutions in Eastern Europe and the [former] Soviet Republics'.

Page 1 of 7
Commented [JH1]: I've changed this because the phase »Iron Curtain « normally referred to under communist-led government from Poland in the North to Yugoslavia in the South (or as Churchill put it, »from Stettin to Trieste«). 
The transition from a mono- to multi-party political system brought parliamentary democracy, protection of human rights, privatisation, private initiative and a declining welfare state. The transition to market economy has also led to precarious employment and unemployment. According to World Bank data, the unemployment ratio for 2012 (as a proportion of the total labour force) was between $10 \%$ and $15 \%$ in the Baltic States, though lower for Czech Republic (7.0\%), Russian Federation (5.5\%), and China (4.5\%). At the same time, migration has increased (Holford 2008, Vassilev 2011). In the case of post-Communist Europe, people are faced with challenges of foreign workers, students and cultural diversity - which require special kinds of competences and measures at national and local levels. The speed of China's development is generating a demand for experts and joint-venture enterprises: in some ways, therefore, it is facing similar issues to those in Europe -cultural differences, multiculturalism and understanding one another.

When the post-communist countries joined the EU, they had to adapt to various EU requirements. However, recent research on lifelong learning in Europe has shown the importance of historical, cultural and political development in the post-communist countries covered by the study. Though the adult education sector had been well developed under the socialist regimes, lifelong learning as a concept was introduced by the EU and is relatively new; in Russia it remained practically non-existent. Nevertheless when introduced it was invariably embraced as a 'way to enhance economic growth', an 'addition to labour market policies' (Holford 2008) and in some cases as means to improve social capital. It was not seen as 'the philosophical-political concept of a humanistic, democratic and emancipatory system of learning opportunities for everybody, independent of class, race or financial means, and independent of the age of learner' (Shuetze 2006, p. 290) but as one enabling the EU to become the most competitive, knowledge based economy. Cheng, Jin \& Gu (1998) point out that lifelong learning in China has been closely associated with state manpower planning. In modern times it has had multiple functions. It has been adopted as a means to improve human capital and manpower accumulation, to re-skill the labour force, to address social needs and to give 'legitimacy to [the] once marginalized adult and continuing education sector' (Weifang \& Quortrup, 2010, p.5). Some of its multiple functions are to be 
recognised in EU papers as well, e.g. improving human capital, re-skilling the labour force, addressing social needs.

Schuetze (2006) suggests that the Organisation for Economic Co-operation and Development's (OECD) paper on Recurrent Education (1973) aimed at 'Lifelong Learning for all, marrying the economic rationale with wider societal objectives' ( $p$. 292). He saw five rationales for lifelong learning set out in the OECD paper, relating to (i) the role of knowledge, information and ideas, (ii) the speed of technological change, (iii) inadequate redistribution policies and changing and flexible lifestyles, (iv) active employment policies, and (v) social cohesion for those who missed out educational opportunities. In a way, post-Communist countries can be seen as having endorsed this position. In China, as Weifang and Quortrup (2010, p. 4) note, the concept of lifelong learning was adopted extensively some time after it had been well received by European and some Asian countries.

Research on lifelong learning in Europe has shown that though many governments or educational institutions have adopted the idea of lifelong learning, some use it more as a catch phrase, to be in line with ongoing policy trends. In other words the term lifelong learning is incorporated into 'conventional curricular discourse' but is not always carried through into how the curriculum is organised. In China, according to Weifang and Quortrup (2010), lifelong learning has multiple purposes, some of which are discussed in this issue.

The post-Communist countries are not only facing structural and political changes but also many issues unimagined in socialist times. Some of these are addressed in this Special Issue: organisational learning, cultural differences and cross-border cooperation (Michael Göhlich, Nicolas Engel, Thomas Höhne; Steffi Robak), Europeanization, localisation, glocalisation (Martin Kopecky) and globalisation (Xuhong Wang). Michael Göhlich, Nicolas Engel and Thomas Höhne are researching the "challenges of national, cultural and linguistic borders emerging and growing in Europe without borders". Their focus is on Czech-German cross-border cooperation as a transnational organisational learning process. They investigate how organisations try to create and follow a crossborder agenda while both embedded in their own local circumstances and confronted 
with the challenges of different national policies. They are faced not only with problems of linguistic communication but also different cultural practices, different histories, different sectoral practices and previous political demarcations.

Steffi Robak deals with a similar issue, though with a focus on transnational enterprises which not only transfer products and technology but also develop specific strategies to accompany economic globalization with learning activities within the field of human resource management. She shows that 'transnational enterprises in China do not have integrated learning culture concepts combining further vocational training and cultural education' as is often the case for European. Though the idea of lifelong learning has been present in China for quite a while, as Cheng, Jin \& Gu (1998) argue, Robak's paper shows that enterprise and 'learning culture do not form unique concepts of lifelong learning corresponding to learning and educational interests and necessities of the expatriates'.

From a different angle, Xuhong Wang and Terri Seddon focus on the conceptual challenges of lifelong learning for Chinese, English and Australian universities. They reflect on how national governments in Australia, China and the UK 'are redesigning education policies in order to meet the challenges brought by the globalizing processes'. If these processes affect national policies they also affect research and teaching practices as well individuals' learning and development strategies. Around the world the workplace is changing; universities are also changing as working environments. How much, and to what extent, do the global imperatives of policies for lifelong learning and education impact on Chinese academics' lives and learning?

Finally, Martin Kopeckŷ's paper focuses on the globalization and Europeanisation of Czech society, its transformation into a post-communist society, and the ready acceptance of the 'mainstream' policies propagated by transnational bodies - the OECD in particular. He interprets this phenomenon as resulting from the Czech government's relatively weak interest in lifelong learning - a view supported by other research (e.g. Holford et al., 2008).

Taken together, the contributions included in this Special Issue invite the reader to consider the approaches to adult education and lifelong learning in post-Communist 
countries, the challenges of crossing national, cultural and linguistic borders, the need for intercultural competences in Europeanised and other, globalised, contexts and the influence of transnational organisations on national educational policies.

What conclusions can we draw? What questions should we ask? Do education systems, either within Europe or outside, prepare people to deal with cultural differences? Who else, apart from educators, should prepare people for different cultures and their particular demands? Considering that education prepares people to reflect, to consider and to keep an open mind to differences and similarities, where do we learn about nuances in speech and body language? One definition of education is that it changes people: does it prepare them to become empathic, understanding and prepared to change their ingrained behaviour and practices accumulated over many years? Education can do much, but expectations of what it can achieve are often too high. Nevertheless some tentative suggestions seem to emerge from the four different yet, in a way, similar contributions to this Special Issue. In many countries the idea of lifelong learning has long been embedded in the cultures of many countries, but its connotations have differed. Globalisation and transnationalisation processes are propagating one particular view of lifelong learning, adapting both the academic world and economies to one, particular understanding, leaving its more humane and humanistic aspects of it to the experts and dreamers. However the world has become interdependent: it hardly seems appropriate to speak of cultural 'borrowings' when the seeds were already present. However, we can certainly expand the existing parameters, and build on them - at the same time taking care not to introduce new forms without a wider consultation.

The articles included in this Special Issue all arise from the inaugural conference of ESREA's Research Network on Policy Studies in Adult Education, held at the University of Nottingham in the United Kingdom in 2012. This provided a forum for discussion and debate among nearly eighty scholars committed to inquiry into the nature and significance of policy in adult education. The conference theme, 'Transnationalisation of Educational Policy Making: Implications for Adult \& Lifelong Learning', had global reach: neither the conference nor the Research Network is concerned with Europe alone. Of around fifty papers presented, several have already 
been published in special issues of two journals. Eight articles in Globalisation, Societies and Education (Milana, Holford \& Mohorčič Špolar, 2014) explored the theme 'Adult and Lifelong Education: Global, National and Local Perspectives'.

Nine,focussing on adult education in the EU, and the EU's role in relation to the world, have appeared in the International Journal of Lifelong Education (Holford, Milana \& Mohorčič Špolar, 2014). The Network's second conference, at Aalborg University, Denmark, was held in June 2014: various publications are also planned, based on papers contributed there.

Vida Mohorčič Špolar, Faculty of Arts, University of Maribor John Holford, School of Education, University of Nottingham

Marcella Milana, Department of Education, Aarhus University, Copenhagen

\section{References}

Cheng Kai-ming, Jin Xinhuo, Gu Xiaobo (1998): From Training to Education, Lifelong Learning in China. Comparative Education 35(2), pp. 119-129.

Faure, E., Herrera, F., Kaddoura, A.R., Lopes, H., Petrovsky, A.V., Rahnema, M., Champion Ward, F. (1972): Learning to be. The world of education today and tomorrow. Unesco. Paris.

Holford, J., Milana, M., \& Mohorčič Špolar, V. (eds.) (2014) Adult and Lifelong Education: The European Union, its member states and the world. Special Issue of International Journal of Lifelong Education 33(3).

Holford, J., Riddell, S., Weedon, E., Litjens, J., Hannan, G. (2008). Patterns of Lifelong Learning: Policy \& Practice in an Expanding Europe. Vienna: Lit Verlag GmbH.

Ma, Shu-Yun (1998). Third World studies, development studies and post-communist studies: definitions, distance and dynamism. Third World Quarterly 19(3), pp. 339348. 
Milana, M., Holford, J. \& Mohorčič Špolar, V. (eds.) (2014) Adult and Lifelong Education: Global, National and Local Perspectives. Special Issue of Globalisation, Societies and Education 12(1).

OECD (1973). Recurrent Education: A Strategy for Lifelong Learning. Paris.

Rossen Vassilev, R. (2011). The Tragic Failure of "Post-Communism" in Eastern

Europe. March 8 . Retrieved $8^{\text {th }}$ July 2014 from
http://www.globalresearch.ca/index.php?context=va\&aid=23616.

Shuetze, H.G. (2006): International Concepts and agendas of Lifelong Learning. Compare 36(3), pp. 289-306.

Weifang, M. \& Qvortrup, L. (eds.) (2010) Frameworks for Supporting Lifelong Learning. Beijing: Tongxin Publishing House. 